\title{
IDENTIFICATION AND CHARACTERIZATION OF THE HUMAN NOL7 GENE PROMOTER
}

\author{
Tanmayi P. Mankame, Guolin Zhou, and Mark W. Lingen \\ Departments of Pathology, Medicine and Radiation \& Cellular Oncology, The University of \\ Chicago, Chicago, IL
}

\begin{abstract}
$N O L 7$ is a candidate tumor suppressor gene that localizes to $6 \mathrm{p} 23$, a chromosomal region frequently associated with loss of heterozygosity in a number of malignancies including cervical cancer (CC). Re-expression of NOL7 in CC cells suppresses in vivo tumor growth by $95 \%$ and alters the angiogenic phenotype by modulating the expression of VEGF and TSP1. Here, we describe the determination of two NOL7 transcriptional start sites (TSS), the cloning of its regulatory promoter region, and the identification of transcription factors that regulate its expression. Using 5' Rapid amplification of complementary DNA ends (RACE), two transcriptional start sites were identified. Deletion analysis determined that the essential elements required for the optimal promoter activity of $N O L 7$ were $560 \mathrm{bp}$ upstream of its translation start site. In silico analysis suggested that the promoter region contained potential binding sites for the SP1, c-Myc and RXRa transcription factors as well as an overall GC content of greater than $60 \%$. Chromatin immunoprecipitation (ChIP) confirmed that SP1, c-Myc and RXRa bound to the NOL 7 promoter region. Finally, we demonstrate that NOL7 expression was positively regulated by c-Myc and RXRa. These results demonstrate that the NOL7 promoter region possesses each of the key elements of a TATA-less promoter. In addition, the positive regulation of NOL7 by c-Myc and RXRa provides additional mechanistic insights into the potential role of NOL7 in CC and other malignancies.
\end{abstract}

\section{Keywords}

NOL7; Transcription; TATA-less promoter; c-Myc; RXRa

\section{Introduction}

Cervical Cancer (CC) is the second most common malignancy in women worldwide after breast cancer (American Cancer Society, 2008). HPV infection is observed in 99\% of CC cases. However additional cooperating genetic alterations are required for malignant transformation (Lazo, 1999; Walboomers et al., 1999; Kaufmann et al., 2002; Branca et al., 2006; Narisawa-Saito et al., 2008). NOL7 is a novel tumor suppressor gene which localizes

() 2010 Elsevier B.V. All rights reserved.

Address correspondence, proofs and reprints to: Mark W. Lingen, Department of Pathology, The University of Chicago, 5841 S. Maryland Avenue MC6101, Chicago, IL 60637, Tel.: 773-702-5548, Fax: 773-834-7644, mark.lingen@uchospitals.edu.

\section{Conflict of Interest}

The authors declare no conflict of interest.

Publisher's Disclaimer: This is a PDF file of an unedited manuscript that has been accepted for publication. As a service to our customers we are providing this early version of the manuscript. The manuscript will undergo copyediting, typesetting, and review of the resulting proof before it is published in its final citable form. Please note that during the production process errors may be discovered which could affect the content, and all legal disclaimers that apply to the journal pertain. 
to 6p23, a region frequently lost in CC (Janet S. Rader, 2000; Chatterjee et al., 2001; Mazurenko et al., 2003; Hasina et al., 2006; American Cancer Society, 2008). In addition, 6 p23 loss is also observed in other malignancies including hormone refractory breast cancer, leukemias, lymphomas, osteosarcomas, retinoblastoma and nasopharyngeal carcinomas (Fleischman et al., 1983; Hoyle et al., 1988; Jadayel et al., 1995; Nemani et al., 1996; Mutirangura et al., 1997; Liao et al., 1998; Nagai et al., 1999; Chen et al., 2000; Nakase et al., 2000; Shao et al., 2000; Achuthan et al., 2001; Giagounidis et al., 2001; Lung et al., 2001; Batanian et al., 2002; Starostik et al., 2002; Fan and Rizkalla, 2003; Amare Kadam et al., 2004; Lim et al., 2004; Takeshita et al., 2004; Gasowska-Giszczak et al., 2005). NOL7 is a $29 \mathrm{kDa}$ protein that localizes to both the nucleus and nucleolus. Reintroduction of NOL7 into CC tumor cells alters the angiogenic phenotype by modulating the expression of VEGF and TSP1, thereby inhibiting in vivo tumor growth (Hasina et al., 2006). Allelic loss of $N O L 7$ has been identified in $40 \%$ of CC cell lines and tumor samples by fluorescent in situ hybridization (FISH) analysis. Similarly, NOL $7 \mathrm{mRNA}$ expression was also reduced in $38 \%$ of CC cell lines (Hasina et al., 2006).

Nothing is known regarding the transcriptional activation or regulation of NOL7. Therefore, the aim of this work was to identify and characterize the promoter region of the human $N O L 7$ gene. We have determined two transcriptional start sites of $N O L 7$ and defined the promoter region immediately upstream of these sites. In silico examination of the promoter region predicted SP1, c-Myc and RXRa as potential transcription factors. Further, we validated these predictions, showing that SP1, c-Myc and RXRa bind to the NOL7 promoter and that c-Myc and RXRa positively regulate $N O L 7$ expression.

\section{Materials and Methods}

\subsection{Cell Culture}

HeLa and HEK293T cell lines (ATCC) were cultured in DMEM (Invitrogen) supplemented with $10 \% \mathrm{FBS}, 100 \mu \mathrm{g} / \mathrm{ml}$ penicillin-streptomycin (Gemini Bioproducts) and maintained at $37^{\circ} \mathrm{C}$ in a $5 \% \mathrm{CO}_{2}-95 \%$ air environment in humidified incubators.

\subsection{5' RACE Assay}

Total RNA was extracted from cell lines using TRIzol® reagent (Invitrogen) and quantified spectrophotometrically. The 5' RACE kit (Invitrogen, 18374-058) was used according to the manufacturer's instructions. Briefly, cDNA was synthesized using the RT Primer 5' GTCTCCCGCACTCGCCGCTC-3" and a dCTP tail was added to it. This "C-tailed cDNA" was then amplified using a nested PCR primer $5^{\prime}$-CCTTCCTCGTCTTCCTCCAG- $3^{\prime}$ and the primer provided in the kit, using cycling parameters: $94{ }^{\circ} \mathrm{C}$ for $1 \mathrm{~min},\left(94^{\circ} \mathrm{C}\right.$ for $30 \mathrm{~s}, 55$ ${ }^{\circ} \mathrm{C}$ for $30 \mathrm{~s}, 72{ }^{\circ} \mathrm{C}$ for $\left.1 \mathrm{~min}\right) 30$ cycles, $72{ }^{\circ} \mathrm{C}$ for $7 \mathrm{~min}$. The primer design was based on the NOL 7 mRNA sequence (NCBI ID: NM_016167). The 5'-RACE PCR products were resolved on $2 \%$ agarose gel, the bands were excised, cloned in to pCR ${ }^{2} 4 \mathrm{TOPO}$ sequencing vector (Invitrogen) and sequenced.

\subsection{PCR Amplification and Cloning}

Human chromosome 6 cosmid clone, LA0634c7 (LANL Human Chromosome 6 Library, HGMP Resource Centre) spanning base pairs 13,545,500 to 13,585,060 (NCBI ID: NT_007592.15) was used as a template for amplifying the NOL7 upstream fragments, using primers described in Supplementary figure 1. PCR products were digested with BgIII and HindIII restriction enzymes (New England Biolabs) and resolved on a 2\% agarose gel. The bands were excised, purified (Gel Extraction Kit, Qiagen) and cloned into the pGL3 basic vector (Promega) digested with the same enzymes, to obtain the deletion constructs described in Figure 3. $p S V$ - $\beta$-Galactosidase control vector was purchased from Promega. 
For c-Myc cloning, SuperScript ${ }^{\circledR}$ III Kit (Invitrogen) was used to generate cDNA from HeLa RNA as per the manufacturer's instructions. The c-Myc coding region (NCBI ID: NM_002467.3) was amplified from the HeLa cDNA using primers, 5' GGCACTTTGCACTGGAACTT- $3^{\prime}$ and $5^{\prime}$-CGCACAAGAGTTCCGTAGCT-3' and cloned into pCDNA3.1 DEST40 vector (Invitrogen, 12274-015), which has a c-terminal V5 tag using the Gateway cloning protocol. PCR was performed using Hi Fi Phusion Master Mix (New England Biolabs) and cycling parameters; $98^{\circ} \mathrm{C}$ for $30 \mathrm{~s},\left(98^{\circ} \mathrm{C}\right.$ for $10 \mathrm{~s}, 64^{\circ} \mathrm{C}$ for $30 \mathrm{~s}, 72^{\circ} \mathrm{C}$ for $\left.3 \mathrm{mins}\right) 35$ cycles and $72^{\circ} \mathrm{C}$ for $10 \mathrm{mins}$. All clones were verified by sequencing and the plasmid DNA was extracted using the Hi-Speed Maxi Prep Kit (Qiagen).

\subsection{In Silico Analysis of NOL7 Promoter Elements}

The EMBOSS-Isochore program was used to identify regions within the $N O L 7$ promoter that were particularly GC-rich (Bernardi, 1995; Pesole et al., 1999; Bernardi, 2000). TESS, Genomatrix and Alggen Promo predication softwares were used to identify the transcription factor binding sites within the promoter (Werner, 2000; Farre et al., 2003; Schug, 2003). These programs were inputted with the $N O L 7$ promoter sequence, as identified by the luciferase assays (13,555,060 to 13,555,590 base pairs, NCBI ID: NT_007592.15). Sequences of the NOL7 upstream region among different species were analyzed using MegAlign software (DNASTAR, Inc). The NOL7 upstream region was defined as the genomic sequence separating the SIRT5 and NOL7 genes in the individual species.

\subsection{Transfections}

Cells were plated in 6 well plates (BD Biosciences) such that they were 70-75\% confluent and co-transfected with $1 \mu \mathrm{g}$ of each promoter construct and $0.5 \mu \mathrm{g} \mathrm{pSV}-\beta$-Galactosidase vector using Lipofectamine 2000 (Invitrogen) as per the manufacturer's protocol. All transfections were performed in duplicate at a given time and repeated a total of three times. Cells were lysed 24 hours after transfection and the cell lysates were used for the luciferase and $\beta$-galactosidase assays. For c-Myc transfection, cell lines were transfected with equal amounts of either pDEST40-c-Myc or pCDNA3.1 DEST40 vector for 24, 48 and 72hrs. Total RNA and protein were extracted from the cells after each of these time points.

\subsection{Luciferase and $\beta$-Galactosidase Assays}

Luciferase and $\beta$-Galactosidase assays were performed using luciferase and $\beta$-Galactosidase assay reagents respectively (Promega) as per the manufacturer's guidelines. Luciferase activity was read using 20/20n Single Tube Luminometer (Turner Biosystems). The $\beta$-gal values were used to normalize the luciferase activity and either the $p G L 3-3.1$ or $p G L 3-2.1$ constructs were used to calibrate the normalized luciferase activity in the other constructs.

\subsection{Retinoic Acid Treatment}

Cells were grown to 70-75\% confluence in DMEM supplemented with $10 \%$ FBS, after which they were switched to DMEM containing 1\% BSA (Sigma), to eliminate artifacts caused by retinoids known be present in serum in small quantities. After growing cells overnight in the $1 \%$ BSA medium, they were treated with $1 \mu \mathrm{M}$ of ATRA (Sigma) or 9-cis RA (Sigma) or DMSO for $4 \mathrm{hrs.} \mathrm{After} \mathrm{treatment,} \mathrm{the} \mathrm{cells} \mathrm{were} \mathrm{used} \mathrm{to} \mathrm{generate} \mathrm{chromatin}$ preparations or to extract total RNA for quantitative RT PCR as described below. The ATRA treatment was repeated three separate times.

\subsection{Chromatin Immunoprecipitation (ChIP) Assays}

ChIP assays were performed for the transcription factors c-Myc, RXRa and SP1. Cell lines untreated or treated with DMSO or ATRA or 9-cis RA were fixed with $1 \%$ formaldehyde, quenched using 1.25M Glycine, resuspended in SDS lysis buffer and sonicated (10 second 
pulses $\times 5$ at $50 \%$ duty cycle, output 5 , Branson sonifier) to generate chromatin sizes between 200-1000bp. ChIP assay was carried out using EZ-ChIP assay kit (Upstate Biotechnology), according to the manufacturer's instructions. The $100 \mu \mathrm{l}$ of soluble DNA fraction was saved as input (10\%). $5 \mu \mathrm{g}$ of c-Myc (Abcam, ab56), RXRa (Millipore, MAB5478), SP1 (Millipore, 17-601), Mouse IgG (Millipore, 12-371B) and Rabbit IgG (Millipore, 17-601) antibodies were used for the ChIP assay. Each ChIP assay was repeated twice. $2 \mu$ ls of eluted DNA from ChIP and input reactions was used for PCR with primers 537F 5' -TAGAGCGCATTTCTTCCCAT-3' and 1004R 5'-GCGCTAGACCGTCTGACCT $-3^{\prime}$ using program $98^{\circ} \mathrm{c}$ for $30 \mathrm{~s},\left(98^{\circ} \mathrm{c}\right.$ for $20 \mathrm{~s}, 62^{\circ} \mathrm{c}$ for $30 \mathrm{~s}$ and $72^{\circ} \mathrm{c}$ for $\left.30 \mathrm{~s}\right) 19 \mathrm{cycles}$ and $72^{\circ} \mathrm{C}$ for 5 mins. A second PCR was performed using 1-2 $\mu$ ls of the amplicon as a template, this time using nested primers A3F 5' -TCTTCCCTGCCTTGAAATCAA-3' and A3R 5' GGCAGTGGGCGTGTTTCT-3'. The products were resolved on $2 \%$ agarose Gel.

\subsection{Quantitative RT-PCR}

Endogenous $N O L 7$ mRNA expression was determined by quantitative RT PCR (PRISM 7900HT, Applied Biosystems), using Ag-Path ID RT PCR Master mix (Ambion). The TaqMan assays for $N O L 7$ and GAPDH were purchased from Applied Biosystems (Hs00982304_m1 and Hs99999905_m1 respectively). Gene expression was quantified using the relative quantification method, according to the manufacturer's instructions (Biosystems). Briefly, GAPDH cycle threshold (Ct) value of each sample was used to normalize $N O L 7 \mathrm{Ct}$ value for that sample, to calculate its "delta Ct" value. Further, the NOL7 delta Ct values in the ATRA treated or c-Myc transfected cells were normalized to their respective untreated delta $\mathrm{Ct}$ values, to calculate delta delta $\mathrm{Ct}(\mathrm{ddCt})$. The ddCt values were then used to estimate the relative fold change in NOL 7 mRNA expression.

\subsection{Western Blotting}

Cells transfected with pDEST40-c-Myc or pCDNA3.1 DEST40 vectors for various time periods were resuspended in $500-750 \mu \mathrm{l}$ of lysis buffer $(20 \mathrm{mM}$ Tris $\mathrm{pH} 7.5,150 \mathrm{mM} \mathrm{NaCl}$, $1 \mathrm{mM}$ EDTA, $1 \mathrm{mM}$ EGTA, $1 \%$ Triton X-100), and sonicated (10 second pulses $\times 5$ at $30 \%$ duty cycle, output 3 , Branson sonifier). Protein concentration was measured using Bio-Rad protein assay reagent and a Synergy HT microplate reader (BioTEK Instruments). $30 \mu \mathrm{g}$ of protein was separated on 10\% SDS-PAGE gels (Pierce) and transferred to ImmunoblotPVDF membrane (Bio-Rad). The blot was blocked and then incubated with V5 (Invitrogen, R960-CUS) or Actin (Abcam, ab8227) antibodies, followed by the appropriate secondary antibodies. Blots were developed with SuperSignal West Dura Extended Duration Substrate (Pierce) and exposed to film (Denville Scientific).

\section{Results}

\subsection{Identification of NOL7 transcription start sites (TSS)}

As a first step towards defining the promoter region of $N O L 7,5^{\prime}$ RACE was performed to identify the gene's TSS, which is designated as the first nucleotide copied at the $5^{\prime}$ end of the corresponding mRNA (Sandelin et al., 2007). 5' RACE PCR, followed by nested amplification, was performed using total RNA isolated from HeLa cells. This yielded two product sizes of 232 and $143 \mathrm{bp}$ (Fig. 1A). Analysis of these sequences demonstrated that the products corresponded to two distinct transcripts starting at -32 and +60 with respect to the NOL 7 translation start site which will be referred to as +1 throughout the remainder of this report (Fig. 1B). Conventionally, transcriptional initiation is believed to occur from a single focused "TSS" (Bjornsdottir and Myers, 2008; Anish et al., 2009). Therefore, the presence of two distinct transcriptional start sites suggests that $N O L 7$ transcription may be regulated by "non-traditional" mechanisms. 


\subsection{Cloning and Identification of NOL7 Promoter Region}

In order to compare the genomic architecture of $N O L 7$ across different species and identify possible conserved regions, the sequences located upstream of the $N O L 7$ gene were aligned and analyzed in four species (human, chimpanzee, mouse and dog). The genes SIRT5 and $R A N B P 9$ flank $N O L 7$ at its $5^{\prime}$ and $3^{\prime}$ ends respectively in each species, suggesting conservation of genomic architecture (Fig. 2A). However, no specific region conservation was observed in the sequence $5^{\prime}$ upstream of the $N O L 7$ gene (Fig. 2B). Therefore, in order to accurately identify the proximal promoter region, we cloned the $5^{\prime}$ flanking region of the human NOL7 gene. We generated an initial set of three luciferase reporter gene constructs containing deletions of the $N O L 7$ upstream region (Fig. $3 \mathrm{~A}+\mathrm{B}$ ). The longest construct of the three constructs was $3.1 \mathrm{~kb}$ ( $p G L 3-3.1$ ) in length, which extended $-3162 \mathrm{bp}$ upstream of the NOL 7 translation start site and 421 bp downstream of the SIRT5 stop codon (NCBI ID: NM_012241.3) (Fig. 3B). Further, the $3.1 \mathrm{~kb}$ region was divided into 1.2 and $2.1 \mathrm{~kb}$ regions ( $p G L 3-1.2$ and 2.1 respectively; Fig. 3B). To determine the functional significance of the regulatory domains of the $N O L 7$ promoter region, equal amounts of the three constructs, and the promoter less pGL3 basic vector, were individually transfected in HEK293T cells along with the $\beta$-Galactosidase vector. The $1.2 \mathrm{~kb}$ region did not demonstrate any luciferase activity when compared to the pGL3 basic control vector. Conversely, the $2.1 \mathrm{~kb}$ and the 3.1 $\mathrm{kb}$ constructs dramatically increased promoter activity (Fig. 3B). To further characterize the promoter region, we generated four additional deletion constructs by creating $5^{\prime}$ and $3^{\prime}$ truncations of the $2.1 \mathrm{~kb}$ region as depicted in Fig. 3C. The proximal constructs $p G L 3-1 P$ and $p G L 3-1.5 P$ failed to demonstrate significant luciferase activity. Conversely, both of the distal constructs, $p G L 3-1.5 D$ and $p G L 3-1 D$, induced relative luciferase activity that was comparable to $p G L 3-2.1$. Finally, the distal $2.1 \mathrm{~kb}$ region was further characterized by the generation of four additional constructs approximately $0.5 \mathrm{~kb}$ in length, that sequentially spanned the entire distal $2.1 \mathrm{~kb}$ region. The $p G L 3-0.5(4)$ construct demonstrated luciferase activity that was equivalent to the activity expressed by either the $p G L 3-2.1$ or the $p G L 3-3.1$. Conversely, the $p G L 3-0.5$ (1), $p G L 3-0.5$ (2) and $p G L 3-0.5(3)$ failed to demonstrated significant luciferase activity (Fig. 3C). These results demonstrated that the genomic region occupying the -560 to -30 nucleotides upstream of the first NOL7 translation start site contain the essential elements required for the optimal promoter activity of the NOL7 gene.

\subsection{Identification of regulatory elements in the promoter region}

In silico analysis of the promoter by the TESS, PROMO and Genomatrix programs (Werner, 2000; Messeguer et al., 2002; Farre et al., 2003) demonstrated that this region lacked the major eukaryotic promoter elements, such as TATA and CCAAT boxes, implying that the NOL 7 may have a TATA-less promoter. It is now believed only 10-20\% of human proteincoding genes have promoters that contain TATA boxes (Anish et al., 2009). TATA-less promoters are characterized by the presence of multiple TSSs, CpG islands and SP1 transcription factor binding sites (Zhu et al., 2008; Anish et al., 2009). Because NOL7 has two TSSs at positions -32 and +60 respectively (Fig. 1) and lacked the major eukaryotic promoter elements, we searched for the presence of $\mathrm{CpG}$ islands immediately upstream of the TSS. The overall GC content of the promoter region was estimated to be greater than $60 \%$ by the EMBOSS-isochore program (Bernardi, 1995; Pesole et al., 1999; Bernardi, 2000) (Fig. 4A). Using the EMBOSS-CpG plot program it was determined that the NOL7 genomic region contains a large $\mathrm{CpG}$ island about 1120 nucleotides in length, containing 111 CpG dinucleotides (13,554,908 to 13,556,028 bp, NCBI ID: NT_007592) (Rice et al., 2000). Promoter hypermethylation is a common mechanism by which tumor suppressor genes can be silenced in various malignancies including CC (Dong et al., 2001). However, bisulfite sequencing of the $N O L 7$ promoter region from genomic DNA derived from normal cervical epithelium, CC cell lines and CC tumor samples failed to identify persistent sites of 
methylation (Mankame, et al, in submission). This data suggest that $N O L 7$ expression was not regulated by an epigenetic mechanism. However the presence of a $\mathrm{CpG}$ island further supports the hypothesis that $N O L 7$ may be regulated by a "TATA-less promoter". Finally, a search of transcription factor consensus motifs identified two potential SP1 binding sites in the promoter (Fig. 4A+B). To verify that the SP1 transcription factor physically occupied the SP1 sites identified within the NOL7 promoter, a ChIP assay was performed. Immunoprecipitation of cross-linked chromatin from HEK 293T and HeLa cells with antiSP1 polyclonal antibody followed by PCR amplification of the region (the sequence between 13,555,323 and 13,555,447 of NCBI ID: NT_007592) demonstrated that endogenous SP1 protein specifically binds to this region of the NOL7 promoter in both HEK 293T and HeLa cells (Fig. 4C). The data presented above confirms that the NOL7 promoter region possesses each of the key features of a classical "TATA-less" promoter.

\subsection{Regulation of NOL7 expression by c-Myc}

In addition, to the SP1 binding site, in silico analysis of the $N O L 7$ promoter regions consistently predicted the presence of conserved c-Myc and RXRa binding sites (Fig. 4A $+B)$. c-Myc is a transcription factor that coordinates diverse intracellular and extracellular programs necessary for growth and expansion of somatic cells and is commonly deregulated or overexpressed in cancer (Soucek et al., 2008). Analysis of the NOL7 promoter region identified the specific conserved c-Myc binding site "CACGTG" (Fig. 4A+B) (Zeller et al., 2006). In addition, $N O L 7$ was identified as a potential c-Myc target gene by a ChIP-ChIP study conducted by another group (Kim et al., 2008). To verify that c-Myc physically occupied the $N O L 7$ promoter region, a ChIP assay was performed. Immunoprecipitation of cross-linked chromatin from HEK 293T and HeLa cells with anti-c-Myc polyclonal antibody followed by PCR amplification of the region (the sequence between 13,555,323 and 13,555,447 of NCBI ID: NT_007592) demonstrated that endogenous c-Myc protein specifically binds to this region of the NOL7 promoter in both HEK 293T and HeLa cells (Fig. 5A). Next, c-Myc was transfected in cells for various time periods to determine whether it acted as a positive or negative regulator of $N O L 7$ expression. Quantitative RTPCR analysis of c-Myc transfected cells demonstrated an upregulation of endogenous NOL7 mRNA levels in HeLa cells. However this trend was less pronounced in HEK293T cells, although both cell lines exhibited a robust expression of c-Myc protein (Fig. 5B+C).

\subsection{Regulation of NOL7 expression by Retinoic acid via RXRa}

Retinoic X receptor alpha (RXRa) is a nuclear receptor that mediates the biological effects of retinoids by binding to specific sequences in the promoters of target genes and regulating their transcription. 9-cisRA is considered an RXR selective ligand (Chambon, 1996). However, RXRs are known to be obligatory DNA-binding partners for a variety of nuclear receptors, there by broadening the spectrum of their biological activity, to the corresponding nuclear receptor-signaling pathways (Altucci et al., 2007; Desvergne and Gerald, 2007). In addition, recent studies have shown that RXRa is recruited to gene promoters in response to all trans retinoic acid (ATRA) (Saavalainen et al., 2005; Knutson and Clagett-Dame, 2008). As indicated previously, the $N O L 7$ promoter region has two potential RXRa binding sites (Fig. 4A+B). To determine if RXRa bound to the NOL7 promoter upon 9-cis RA treatment, cells were grown in serum free media overnight and then treated with 9-cis RA or DMSO. ChIP analysis of 9-cisRA-treated cells failed to demonstrate a significant association of RXRa with the $N O L 7$ promoter as compared to the DMSO treated cells (Fig. 6A). To determine if $N O L 7$ expression could be alternatively regulated by ATRA, cells were treated with either ATRA or DMSO using the same conditions. ChIP analysis demonstrated binding of RXRa to the NOL7 promoter exclusively in the ATRA treated HEK293T and HeLa cells (Fig. 6B). To determine if ATRA treatment positively or negatively regulated expression of NOL7, its mRNA levels in these cells were evaluated. Quantitative RT-PCR analysis 
showed a robust upregulation of endogenous $N O L 7$ mRNA ( $>2$ fold) in HEK293T and HeLa cell lines treated with ATRA as compared to DMSO (Fig. 6C). Again this induction was more pronounced in HeLa cells. Thus, these experiments indicated that NOL7 was transcriptionally activated by ATRA treatment, in part by the recruitment of RXRa to its promoter region.

\section{Discussion}

HPV infection is believed to be the causative agent in the majority of CC cases. However additional genetic aberrations are required for malignant transformation (Lazo, 1999; Branca et al., 2006; Narisawa-Saito et al., 2008). NOL7 is a candidate tumor suppressor gene, whose expression is commonly lost in CC (Hasina et al., 2006). In order to study the tumor suppressor functions of $N O L 7$, it was necessary to understand the molecular mechanisms behind its transcriptional regulation. This study was designed to identify the promoter region of the NOL 7 gene, as well as the potential transcription factors that regulate its expression. Using a combination of bioinformatics and molecular biology techniques we have characterized the NOL7 promoter, provided evidence that it is a TATA-less promoter, and identified c-Myc and RXRa as positive regulators of NOL7 expression.

By generating a series of deletion constructs of the human NOL7 upstream region, its optimal promoter was defined to be the $560 \mathrm{bp}$ region upstream of the initiation codon (Fig. 3 ). These experiments demonstrated that the highest promoter activity is concentrated within this $560 \mathrm{bp}$ sequence and no enhancers or silencers were found to be present further upstream of this region. Sequence analysis of this region showed that it lacked a "TATA box" which is known to recruit transcriptional machinery needed for efficient expression of a gene (Bjornsdottir and Myers, 2008). Recent bioinformatics studies have suggested that the majority of mammalian gene promoters lack a TATA box, have multiple TSSs and are highly GC rich (Anish et al., 2009). Our 5' RACE analysis demonstrated that the NOL7 promoter contained two transcriptional start sites (Fig. 1) and had a significantly high GC content (> 60\%) (Fig. 4A). Finally, the promoter region contained potential SP1 binding sites and this region was capable of binding SP1 protein as determined by ChIP analysis (Fig. 4). Taken together all these data supported the hypothesis that NOL7has a TATA-less promoter.

In CC, the integration of HPV DNA near the c-Myc locus has been shown to transcriptionally activate the gene (Peter et al., 2006). RNAi mediated HPV E6 and E7 knockdown resulted in the downregulation of c-Myc and its target genes suggesting that malignant transformation in CC may be mediated in part via the regulation of c-Myc by HPV (Kuner et al., 2007). Our ChIP data demonstrates that c-Myc associated with the NOL7 promoter and that overexpression of c-Myc upregulated endogenous NOL7 mRNA levels, indicating the c-Myc positively regulated NOL 7 transcription (Fig. 5). This finding was unexpected considering the oncogenic nature of c-Myc. However it is not unprecedented, as c-Myc is known to transactivate several prominent tumor suppressors such as p53, BRCA1 and PTEN by binding to their respective promoters (Roy et al., 1994; Menssen and Hermeking, 2002; Fernandez et al., 2003). One hypothesis may be that certain cancer related genes respond to deregulated c-Myc levels and are induced in order to activate their specific tumor suppressive pathways. Also of importance is the ability of c-Myc to activate or repress genes depending on the co-activator proteins such as Max or Miz-1 that it associates with (Eilers and Eisenman, 2008). Future studies are required to better understand the relationship between HPV infection, c-Myc and regulation of NOL 7transcription.

ATRA treatment is known to induce growth arrest and cell death in CC cell lines in a dose dependent manner (Arany et al., 2003a; Arany et al., 2003b; Gasowska-Giszczak et al., 
2005; Guo et al., 2006). In addition, treatment with ATRA can modulate the angiogenic phenotype in CC and head and neck cancer (Majewski et al., 1994; Lingen et al., 1996). Treatment with ATRA is also known to suppress the transcription of HPV 16, E6 and E7 proteins (Faluhelyi et al., 2004). Additionally, reduced serum levels of ATRA are associated with HPV-mediated progression to invasive carcinoma (Berlin Grace et al., 2006). Endogenous NOL7 mRNA was upregulated greater than two fold in ATRA treated HEK293T and HeLa cells (Fig. 6C). This induction was accompanied by recruitment of RXRa to the $N O L 7$ promoter (Fig. 6B), supporting the hypothesis that RXRa positively regulates $N O L 7$ expression in response to ATRA treatment. Conversely, ChIP experiments demonstrated that RXRa did not associate with the NOL7 promoter upon 9-cis RA treatment (Fig. 6A), suggesting that RXRa may be recruited to the promoter as a heterodimeric complex that does not respond to 9-cis RA (Altucci et al., 2007). Since RXRa is known to heterodimerize with a number of different nuclear receptors, further investigation is required to identify and characterize additional binding partners of RXRa that may exert differential regulation of NOL7 gene expression (Bugge et al., 1992; Desvergne and Gerald, 2007). It will also be interesting to determine if $N O L 7$ plays a role in ATRA mediated growth arrest, cell death and angiogenesis by acting as a downstream effector of ATRA.

In conclusion, we have determined two transcriptional start sites of $N O L 7$, cloned its regulatory promoter region, and identified the transcription factors that regulate its expression. Our data demonstrate that $N O L 7$ contains a TATA-less promoter and is positively regulated by the c-Myc and RXRa transcription factors. This novel regulation of $N O L 7$ by transcription factors that are intimately involved in carcinogenesis provides additional mechanistic insights into the potential role of NOL7 in CC and perhaps other malignancies.

\section{Supplementary Material}

Refer to Web version on PubMed Central for supplementary material.

\section{Acknowledgments}

We would like to thank Dr. Deborah Lang for her advice and assistance with the luciferase assays.

\section{References}

Achuthan R, Bell SM, Roberts P, Leek JP, Horgan K, Markham AF, MacLennan KA, Speirs V. Genetic events during the transformation of a tamoxifen-sensitive human breast cancer cell line into a drug-resistant clone. Cancer Genet Cytogenet. 2001; 130:166-72. [PubMed: 11675139]

Altucci L, Leibowitz MD, Ogilvie KM, de Lera AR, Gronemeyer H. RAR and RXR modulation in cancer and metabolic disease. Nat Rev Drug Discov. 2007; 6:793-810. [PubMed: 17906642]

Amare Kadam PS, Ghule P, Jose J, Bamne M, Kurkure P, Banavali S, Sarin R, Advani S. Constitutional genomic instability, chromosome aberrations in tumor cells and retinoblastoma. Cancer Genet Cytogenet. 2004; 150:33-43. [PubMed: 15041221]

American Cancer Society, I. Cancer Facts \& Figures 2009. American Cancer Society, Inc; Atlanta: 2008.

Anish R, Hossain MB, Jacobson RH, Takada S. Characterization of transcription from TATA-less promoters: identification of a new core promoter element XCPE2 and analysis of factor requirements. PLoS ONE. 2009; 4:e5103. [PubMed: 19337366]

Arany I, Ember IA, Tyring SK. All-trans-retinoic acid activates caspase-1 in a dose-dependent manner in cervical squamous carcinoma cells. Anticancer Res. 2003a; 23:471-3. [PubMed: 12680251] 
Arany I, Whitehead WE, Ember IA, Tyring SK. Dose-dependent activation of p21WAF1 transcription by all-trans-acid in cervical squamous carcinoma cells. Anticancer Res. 2003b; 23:495-7. [PubMed: 12680256]

Batanian JR, Cavalli LR, Aldosari NM, Ma E, Sotelo-Avila C, Ramos MB, Rone JD, Thorpe CM, Haddad BR. Evaluation of paediatric osteosarcomas by classic cytogenetic and CGH analyses. Mol Pathol. 2002; 55:389-93. [PubMed: 12456778]

Berlin Grace VM, Niranjali Devaraj S, Radhakrishnan Pillai M, Devaraj H. HPV-induced carcinogenesis of the uterine cervix is associated with reduced serum ATRA level. Gynecol Oncol. 2006; 103:113-9. [PubMed: 16554086]

Bernardi G. The human genome: organization and evolutionary history. Annu Rev Genet. 1995; 29:445-76. [PubMed: 8825483]

Bernardi G. Isochores and the evolutionary genomics of vertebrates. Gene. 2000; 241:3-17. [PubMed: 10607893]

Biosystems, A. Relative Quantitation Using Comparative CT Getting Started Guide.

Bjornsdottir G, Myers LC. Minimal components of the RNA polymerase II transcription apparatus determine the consensus TATA box. Nucl Acids Res. 2008; 36:2906-2916. [PubMed: 18385157]

Branca M, Giorgi C, Ciotti M, Santini D, Di Bonito L, Costa S, Benedetto A, Bonifacio D, Di Bonito P, Paba P, Accardi L, Mariani L, Ruutu M, Favalli C, Syrjanen K. Down-regulated nucleoside diphosphate kinase $\mathrm{nm} 23-\mathrm{H} 1$ expression is unrelated to high-risk human papillomavirus but associated with progression of cervical intraepithelial neoplasia and unfavourable prognosis in cervical cancer. J Clin Pathol. 2006; 59:1044-51. [PubMed: 16537673]

Bugge TH, Pohl J, Lonnoy O, Stunnenberg HG. RXR alpha, a promiscuous partner of retinoic acid and thyroid hormone receptors. EMBO J. 1992; 11:1409-18. [PubMed: 1314167]

Chambon P. A decade of molecular biology of retinoic acid receptors. FASEB J. 1996; 10:940-54. [PubMed: 8801176]

Chatterjee A, Pulido HA, Koul S, Beleno N, Perilla A, Posso H, Manusukhani M, Murty VV. Mapping the sites of putative tumor suppressor genes at $6 \mathrm{p} 25$ and $6 \mathrm{p} 21.3$ in cervical carcinoma: occurrence of allelic deletions in precancerous lesions. Cancer Res. 2001; 61:2119-23. [PubMed: 11280775]

Chen Z, Issa B, Brothman LJ, Hendricksen M, Button D, Brothman AR. Nonrandom rearrangements of $6 \mathrm{p}$ in malignant hematological disorders. Cancer Genet Cytogenet. 2000; 121:22-5. [PubMed: 10958936]

Desvergne, B.; Gerald, L. Vitamins \& Hormones. Academic Press; 2007. RXR: From Partnership to Leadership in Metabolic Regulations; p. 1-32.

Dong SM, Kim HS, Rha SH, Sidransky D. Promoter hypermethylation of multiple genes in carcinoma of the uterine cervix. Clin Cancer Res. 2001; 7:1982-6. [PubMed: 11448914]

Eilers M, Eisenman RN. Myc's broad reach. Genes \& Development. 2008; 22:2755-2766. [PubMed: 18923074]

Faluhelyi Z, Rodler I, Csejtey A, Tyring SK, Ember IA, Arany I. All-trans retinoic acid (ATRA) suppresses transcription of human papillomavirus type 16 (HPV16) in a dose-dependent manner. Anticancer Res. 2004; 24:807-9. [PubMed: 15161031]

Fan YS, Rizkalla K. Comprehensive cytogenetic analysis including multicolor spectral karyotyping and interphase fluorescence in situ hybridization in lymphoma diagnosis. a summary of 154 cases. Cancer Genet Cytogenet. 2003; 143:73-9. [PubMed: 12742158]

Farre D, Roset R, Huerta M, Adsuara JE, Rosello L, Alba MM, Messeguer X. Identification of patterns in biological sequences at the ALGGEN server: PROMO and MALGEN. Nucl Acids Res. 2003; 31:3651-3653. [PubMed: 12824386]

Fernandez PC, Frank SR, Wang L, Schroeder M, Liu S, Greene J, Cocito A, Amati B. Genomic targets of the human c-Myc protein. Genes Dev. 2003; 17:1115-29. [PubMed: 12695333]

Fleischman EW, Prigogina EL, Iljinskaja GW, Konstantinova LN, Puchkova GP, Volkova MA, Frenkel MA, Balakirev SA. Chromosomal rearrangements with a common breakpoint at $6 \mathrm{p} 23$ in five cases of myeloid leukemia. Hum Genet. 1983; 64:254-6. [PubMed: 6576981]

Gasowska-Giszczak U, Darmochwal-Kolarz D, Kwasniewska A, Dziubinska-Parol I, Rolinski J, Oleszczuk J. Apoptosis of HeLa cell lines incubated with retinol. Eur J Obstet Gynecol Reprod Biol. 2005; 119:119-22. [PubMed: 15734096] 
Giagounidis AAN, Hildebrandt B, Heinsch M, Germing U, Aivado M, Aul C. Acute basophilic leukemia. European Journal Of Haematology. 2001; 67:72-76. [PubMed: 11722593]

Guo JM, Xiao BX, Kang GZ, Liu DH, Chen H, Zhang S, Zhang XN. Suppression of telomerase activity and arrest at $\mathrm{G} 1$ phase in human cervical cancer HeLa cells by all-trans retinoic acid. Int $\mathrm{J}$ Gynecol Cancer. 2006; 16:341-6. [PubMed: 16445656]

Hasina R, Pontier AL, Fekete MJ, Martin LE, Qi XM, Brigaudeau C, Pramanik R, Cline EI, Coignet LJ, Lingen MW. NOL7 is a nucleolar candidate tumor suppressor gene in cervical cancer that modulates the angiogenic phenotype. Oncogene. 2006; 25:588-98. [PubMed: 16205646]

Hoyle CF, Sherrington P, Hayhoe FG. Translocation (3;6)(q21; p21) in acute myeloid leukemia with abnormal thrombopoiesis and basophilia. Cancer Genet Cytogenet. 1988; 30:261-7. [PubMed: 3422580]

Jadayel D, Calabrese G, Min T, van Rhee F, Swansbury GJ, Dyer MJ, Maitland J, Palka G, Catovsky D. Molecular cytogenetics of chronic myeloid leukemia with atypical $t(6 ; 9)$ (p23; q34) translocation. Leukemia. 1995; 9:981-7. [PubMed: 7596189]

Janet S, Rader YL, Huettner Phyllis C, Xu Zhiqiang, Gerhard Daniela S. Cervical cancer suppressor gene is within $1 \mathrm{cM}$ on 6p23. Genes, Chromosomes and Cancer. 2000; 27:373-379. [PubMed: 10719367]

Kaufmann AM, Backsch C, Schneider A, Durst M. HPV induced cervical carcinogenesis: molecular basis and vaccine development. Zentralbl Gynakol. 2002; 124:511-24. [PubMed: 12796844]

Kim J, Lee JH, Iyer VR. Global identification of Myc target genes reveals its direct role in mitochondrial biogenesis and its E-box usage in vivo. PLoS ONE. 2008; 3:e1798. [PubMed: 18335064]

Knutson DC, Clagett-Dame M. atRA Regulation of NEDD9, a gene involved in neurite outgrowth and cell adhesion. Archives of Biochemistry and Biophysics. 2008; 477:163-174. [PubMed: 18585997]

Kuner R, Vogt M, Sultmann H, Buness A, Dymalla S, Bulkescher J, Fellmann M, Butz K, Poustka A, Hoppe-Seyler F. Identification of cellular targets for the human papillomavirus E6 and E7 oncogenes by RNA interference and transcriptome analyses. J Mol Med. 2007; 85:1253-62. [PubMed: 17589817]

Lazo PA. The molecular genetics of cervical carcinoma. Br J Cancer. 1999; 80:2008-18. [PubMed: 10471054]

Liao SK, Perng YP, Shen YC, Chung PJ, Chang YS, Wang CH. Chromosomal abnormalities of a new nasopharyngeal carcinoma cell line (NPC-BM1) derived from a bone marrow metastatic lesion. Cancer Genet Cytogenet. 1998; 103:52-8. [PubMed: 9595045]

Lim G, Karaskova J, Vukovic B, Bayani J, Beheshti B, Bernardini M, Squire JA, Zielenska M. Combined spectral karyotyping, multicolor banding, and microarray comparative genomic hybridization analysis provides a detailed characterization of complex structural chromosomal rearrangements associated with gene amplification in the osteosarcoma cell line MG-63. Cancer Genet Cytogenet. 2004; 153:158-64. [PubMed: 15350306]

Lingen M, Polverini P, Bouck N. Retinoic acid induces cells cultured from oral squamous cell carcinomas to become anti-angiogenic. Am J Pathol. 1996; 149:247-258. [PubMed: 8686749]

Lung ML, Choi CV, Kong H, Yuen PW, Kwong D, Sham J, Wei WI. Microsatellite allelotyping of chinese nasopharyngeal carcinomas. Anticancer Res. 2001; 21:3081-4. [PubMed: 11712814]

Majewski S, Szmurlo A, Marczak M, Jablonska S, Bollag W. Synergistic effect of retinoids and interferon alpha on tumor-induced angiogenesis: Anti-angiogenic effect on HPV-harboring tumorcell lines. International Journal of Cancer. 1994; 57:81-85.

Mazurenko NN, Beliakov IS, Bliev A, Guo Z, Hu X, Vinokurova SV, Bidzhieva BA, Pavlova LS, Ponten J, Kiselev FL. Cervical carcinoma progression-associated genetic alterations on chromosome 6. Mol Biol (Mosk). 2003; 37:472-81. [PubMed: 12815954]

Menssen A, Hermeking H. Characterization of the c-MYC-regulated transcriptome by SAGE: identification and analysis of c-MYC target genes. Proc Natl Acad Sci U S A. 2002; 99:6274-9. [PubMed: 11983916] 
Messeguer X, Escudero R, Farre D, Nunez O, Martinez J, Alba MM. PROMO: detection of known transcription regulatory elements using species-tailored searches. Bioinformatics. 2002; 18:333334. [PubMed: 11847087]

Mutirangura A, Tanunyutthawongese C, Pornthanakasem W, Kerekhanjanarong V, Sriuranpong V, Yenrudi S, Supiyaphun P, Voravud N. Genomic alterations in nasopharyngeal carcinoma: loss of heterozygosity and Epstein-Barr virus infection. Br J Cancer. 1997; 76:770-6. [PubMed: 9310244]

Nagai H, Kinoshita T, Suzuki H, Hatano S, Murate T, Saito H. Identification and mapping of novel tumor suppressor loci on 6p in diffuse large B-cell non-Hodgkin's lymphoma. Genes Chromosomes Cancer. 1999; 25:277-83. [PubMed: 10379874]

Nakase K, Wakita Y, Minamikawa K, Yamaguchi T, Shiku H. Acute promyelocytic leukemia with $\operatorname{del}(6)(p 23)$. Leuk Res. 2000; 24:79-81. [PubMed: 10634650]

Narisawa-Saito M, Yoshimatsu Y, Ohno S, Yugawa T, Egawa N, Fujita M, Hirohashi S, Kiyono T. An in vitro multistep carcinogenesis model for human cervical cancer. Cancer Res. 2008; 68:5699_ 705. [PubMed: 18632622]

Nemani M, Bellanne-Chantelot C, Cohen D, Cann HM. Detection of triplet repeat sequences in yeast artificial chromosomes using oligonucleotide probes: application to the SCA1 region in 6p23. Cytogenet Cell Genet. 1996; 72:5-8. [PubMed: 8565633]

Pesole G, Bernardi G, Saccone C. Isochore specificity of AUG initiator context of human genes. FEBS Lett. 1999; 464:60-2. [PubMed: 10611483]

Peter M, Rosty C, Couturier J, Radvanyi F, Teshima H, Sastre-Garau X. MYC activation associated with the integration of HPV DNA at the MYC locus in genital tumors. Oncogene. 2006; 25:598593. [PubMed: 16682952]

Rice P, Longden I, Bleasby A. EMBOSS: the European Molecular Biology Open Software Suite. Trends Genet. 2000; 16:276-7. [PubMed: 10827456]

Roy B, Beamon J, Balint E, Reisman D. Transactivation of the human p53 tumor suppressor gene by c-Myc/Max contributes to elevated mutant p53 expression in some tumors. Mol Cell Biol. 1994; 14:7805-15. [PubMed: 7969121]

Saavalainen K, Pasonen-Seppänen S, Dunlop TW, Tammi R, Tammi MI, Carlberg C. The Human Hyaluronan Synthase 2 Gene Is a Primary Retinoic Acid and Epidermal Growth Factor Responding Gene. Journal of Biological Chemistry. 2005; 280:14636-14644. [PubMed: 15722343]

Sandelin A, Carninci P, Lenhard B, Ponjavic J, Hayashizaki Y, Hume DA. Mammalian RNA polymerase II core promoters: insights from genome-wide studies. Nat Rev Genet. 2007; 8:424 436. [PubMed: 17486122]

Schug, J. Baxevanis, AD (Baxevanis, AD)Baxevanis, ADs), Current Protocols in Bioinformatics. J. Wiley and Sons; 2003. Using TESS to Predict Transcription Factor Binding Sites in DNA Sequence.

Shao JY, Wang HY, Huang XM, Feng QS, Huang P, Feng BJ, Huang LX, Yu XJ, Li JT, Hu LF, Ernberg I, Zeng YX. Genome-wide allelotype analysis of sporadic primary nasopharyngeal carcinoma from southern China. Int J Oncol. 2000; 17:1267-75. [PubMed: 11078815]

Soucek L, Whitfield J, Martins CP, Finch AJ, Murphy DJ, Sodir NM, Karnezis AN, Swigart LB, Nasi S, Evan GI. Modelling Myc inhibition as a cancer therapy. Nature. 2008; 455:679-683. [PubMed: 18716624]

Starostik P, Patzner J, Greiner A, Schwarz S, Kalla J, Ott G, Muller-Hermelink HK. Gastric marginal zone B-cell lymphomas of MALT type develop along 2 distinct pathogenetic pathways. Blood. 2002; 99:3-9. [PubMed: 11756145]

Takeshita A, Naito K, Shinjo K, Sahara N, Matsui H, Ohnishi K, Beppu H, Ohtsubo K, Horii T, Maekawa M, Inaba T, Ohno R. Deletion 6p23 and add(11)(p15) leading to NUP98 translocation in a case of therapy-related atypical chronic myelocytic leukemia transforming to acute myelocytic leukemia. Cancer Genet Cytogenet. 2004; 152:56-60. [PubMed: 15193442]

Walboomers JM, Jacobs MV, Manos MM, Bosch FX, Kummer JA, Shah KV, Snijders PJ, Peto J, Meijer CJ, Munoz N. Human papillomavirus is a necessary cause of invasive cervical cancer worldwide. J Pathol. 1999; 189:12-9. [PubMed: 10451482] 
Werner T. Computer-assisted analysis of transcription control regions. Matinspector and other programs. Methods Mol Biol. 2000; 132:337-49. [PubMed: 10547845]

Zeller KI, Zhao X, Lee CW, Chiu KP, Yao F, Yustein JT, Ooi HS, Orlov YL, Shahab A, Yong HC, Fu Y, Weng Z, Kuznetsov VA, Sung WK, Ruan Y, Dang CV, Wei CL. Global mapping of c-Myc binding sites and target gene networks in human B cells. Proc Natl Acad Sci U S A. 2006; 103:17834-9. [PubMed: 17093053]

Zhu J, He F, Hu S, Yu J. On the nature of human housekeeping genes. Trends in Genetics. 2008; 24:481-484. [PubMed: 18786740] 
A

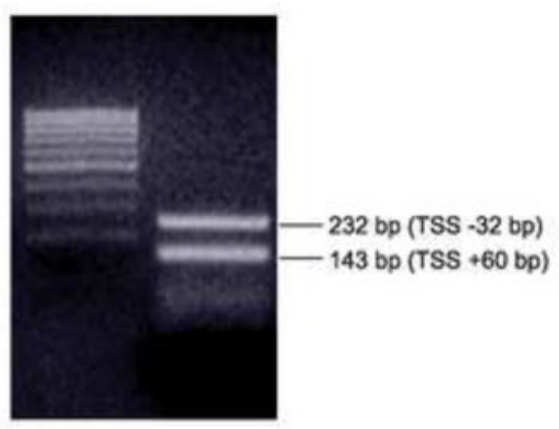

\begin{tabular}{|c|}
\hline $\begin{array}{l}\text { ISS +60 } \\
\text { GCGCCCCGGCGTCGGCGGAGGCGATGGTGACCGAGGGCCAGCTGGCCTCGGAGGAGGA }\end{array}$ \\
\hline GGAGGCGGAGCACGGGCTGTTGCTCGGGCAGCCCAGCAGCGGCGCGGCCGCCGAGCCC \\
\hline 5' RACE Primer \\
\hline CTGGAGGAAGACGAGGAAGGGGACGATGAGTITGACGATGAGGCCCCGGAGGAGCTGACT \\
\hline
\end{tabular}

Figure 1. 
A

\begin{tabular}{|l|l|l|l|l|l|l|l|}
\hline Species & Start & End & Length & NCBI ID & 5' Gene & 3' Gene & Chromosome \\
\hline Homo Sapiens & 13554792 & 13555592 & 800 & NT_007592.15 & SIRT 5 & RANBP9 & 6p23 \\
\hline Mus musculus & 43490572 & 43493745 & 3173 & NC_000079.5 & SIRT 5 & RANBP9 & 13 A44 \\
\hline Pan troglodytes & 13840618 & 13842855 & 2237 & NC_006473.2 & SIRT 5 & RANBP9 & 6 \\
\hline Canis familiaris & 16065036 & 16065441 & 405 & NC_006617.2 & SIRT 5 & RANBP9 & 35 \\
\hline
\end{tabular}

B

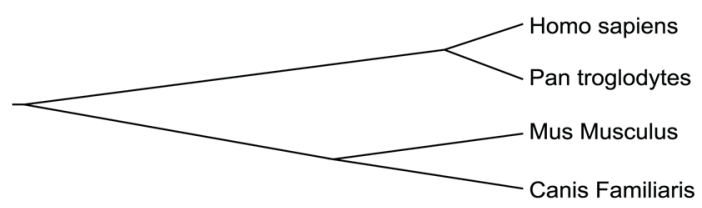

Figure 2.

Gene. Author manuscript; available in PMC 2012 July 31. 
A

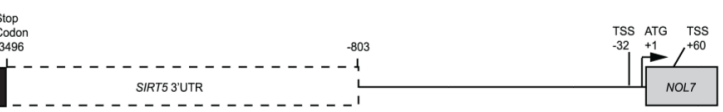

B
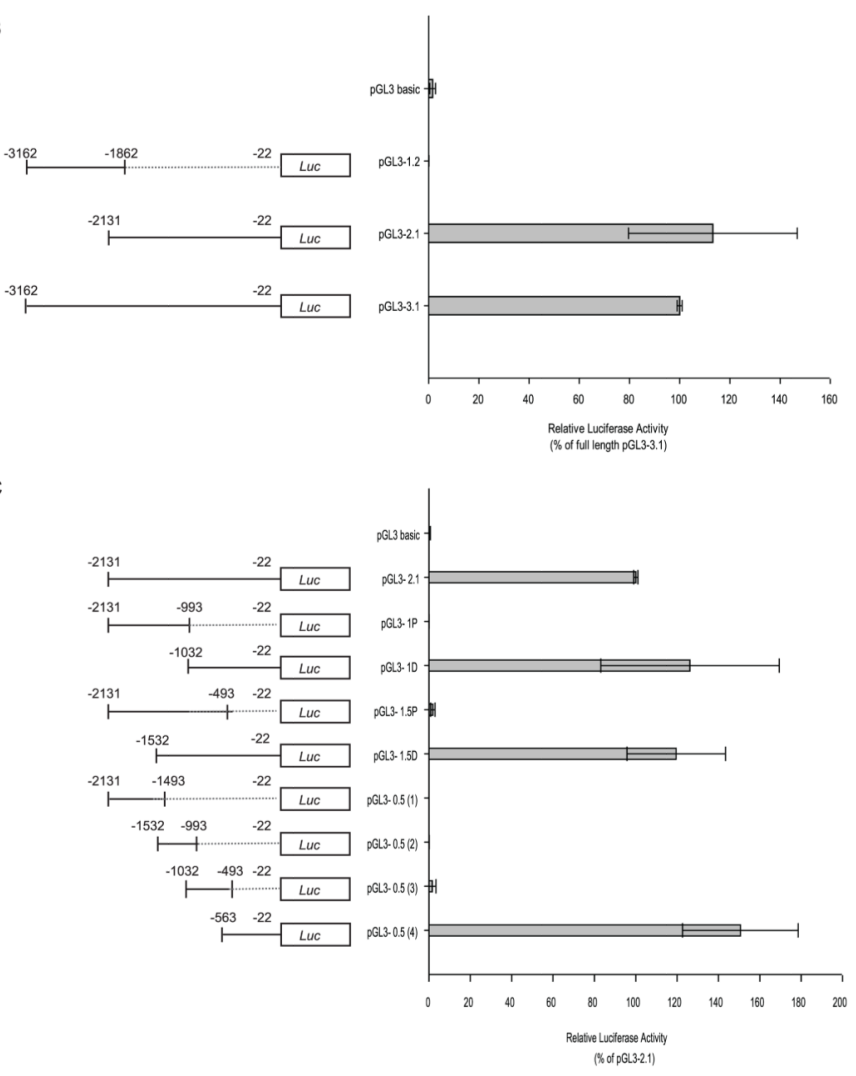

Figure 3. 
A

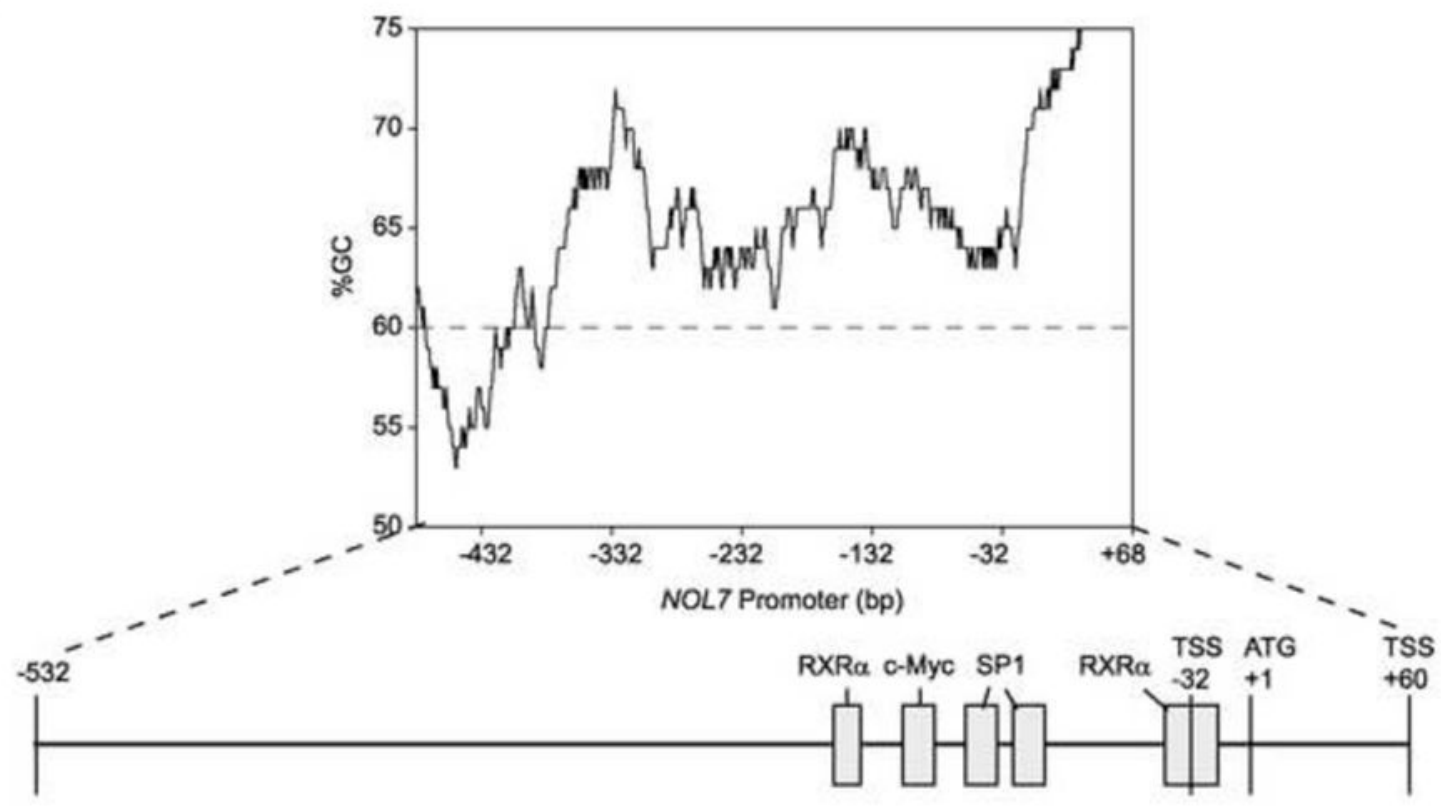

B

\begin{tabular}{|l|l|l|}
\hline $\begin{array}{l}\text { Transcription } \\
\text { Factor }\end{array}$ & Location & Sequence \\
\hline c-Myc & -178 to -164 & tggcCACGtggaa \\
\hline$R \times R \alpha$ & -44 to -19 & ctgcttccgggtcagAGGTcagacg \\
\hline$R \times R \alpha$ & -207 to -201 & gGGTCc \\
\hline SP1 & -115 to -100 & ggacgGGTGgggcgc \\
\hline SP1 & -143 to -128 & ggaagGGCGtggcct \\
\hline
\end{tabular}

C

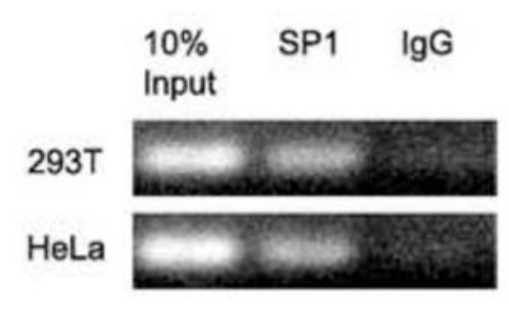

Figure 4. 
A

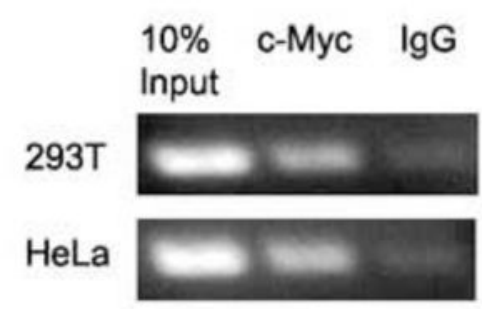

B

\section{C}
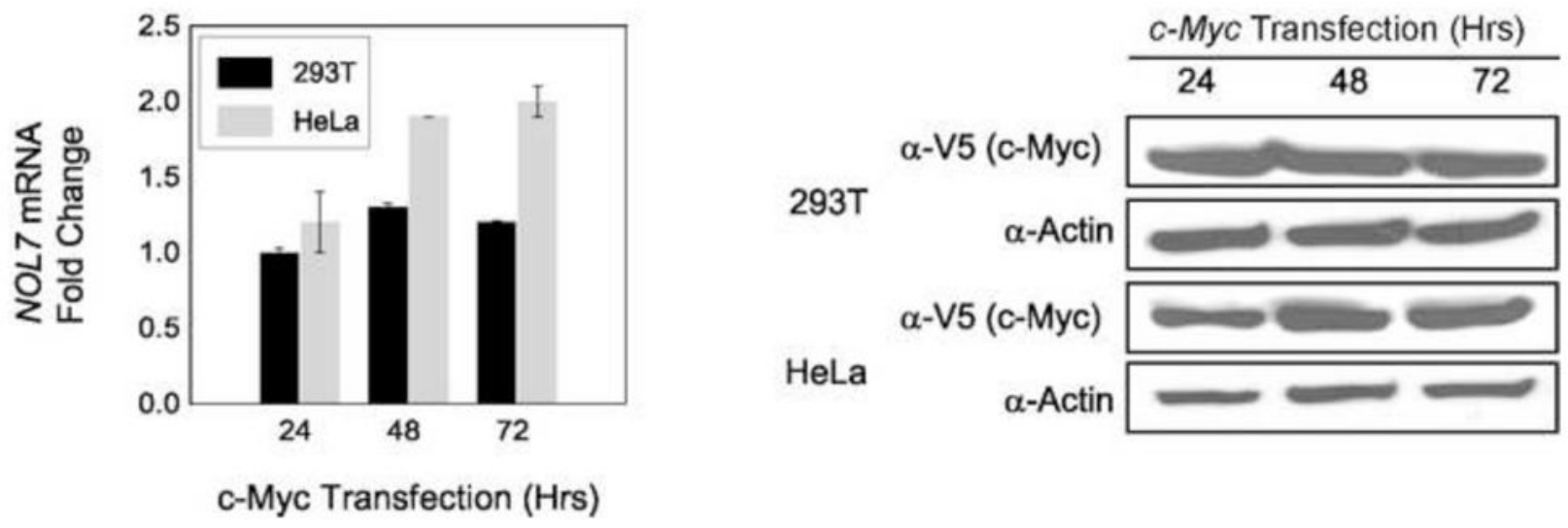

Figure 5. 
A

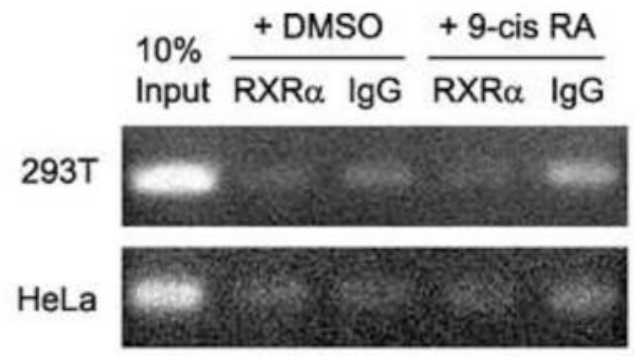

B

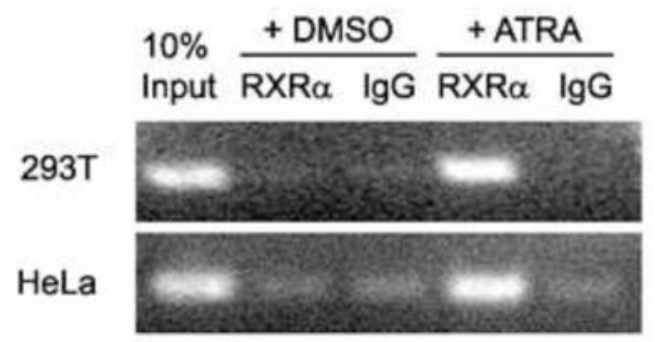

C

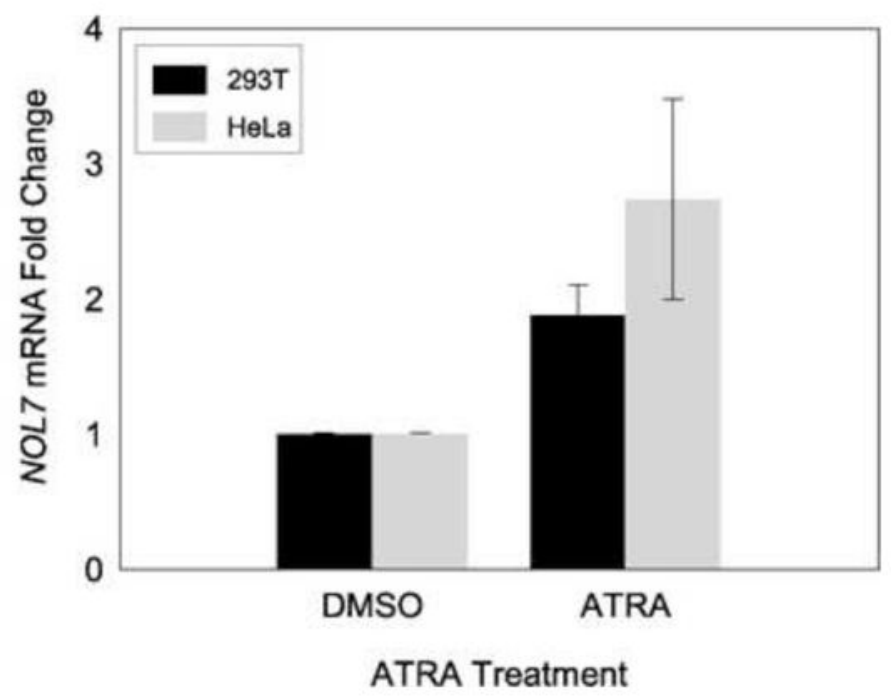

Figure 6. 